\title{
Practical Exploration on Public Art Education of Non-government HEIs in Henan
}

\author{
Jing Chen \\ Academic Affairs Office \\ Sias International University \\ Zhengzhou University \\ Zhengzhou, Henan, China 451110
}

\begin{abstract}
Public art education in higher education institutions (HEIs) is an important part of educational activities in HEIs. Aimed at the current public art education in nongovernment, HEIs in Henan Province has a loose institution setting, single course content and forms, weak high-level teaching staff, insufficient funds of activities and less achievements in teaching and scientific research, and based on the demands of talent training mode of non-government HEIs under the new situation, the public art education in HEIs should set up effective management institutions, innovate management modes, enrich course content and forms, arouse the learning interest of students, strengthen the teaching staff construction of the public art education, increase the fund investment in the public art education, enhance the cultivation work of achievements in teaching and scientific research and strengthen the local and international art and culture exchange and cooperation.
\end{abstract}

\section{Keywords—non-government HEIs; public art education}

\section{INTRODUCTION}

In order to fully implement the national guiding principle for the education, strengthen the art education work in schools step up efforts to advance the quality-oriented education and promote integrated development of students, the Ministry of Education published the Regulations on the School Art Education Work on July 25, 2002. In addition, the Ministry of Education issued the notice of the Public Art Education Course Guidelines for the National Regular Higher Education Institutions in 2006, which made related regulations on the concrete setting of the public art education courses. Public art education in HEIs is the important way and content for implementation of aesthetical education in HEIs and an integral part of quality-oriented education as well as an important component of educational activities in HEIs. Therefore, the public art education in HEIs undertakes larger social mission and responsibility. The HEIs should fully recognize the important role of the public art education, fully implement the educational guiding principles and policies of the Party, actually list all works of the public art education on the important agenda of HEIs, really implement all policies

This paper is the key project in school-level teaching reform of Sias International University of Zhengzhou University in 2016 and the project No. is 2016JGZD08.

About the author: Jing Chen, born on May 12, 1983, female, Native place Sanmenxia, Henan, Teaching Affairs Office, Sias International University of Zhengzhou University, lecturer, master of higher pedagogy, Research direction: higher education management. and measures and speed up the development of all works of the public art education in HEIs.

\section{ANALYSIS OF CURRENT SitUATION OF PUBLIC ART} EDUCATION IN NON-GOVERNMENT HEIS IN HENAN PROVINCE

\section{A. Loose Institution Setting}

In the Public Art Education Course Guidelines for the National Regular Higher Education Institutions, the Ministry of Education explicitly requires that "in order to ensure the setting and teaching quality of selective art courses, the regular higher education institutions should set up specialized administrative department and education institutions for public art courses and strengthen the construction of teaching staff of public art education.". According to the investigation and study, the author finds that a few non-government HEIs in Henan Province do not separately set up administrative department and education institutions of public art courses; some HEIs have strong passivity in the setting of administrative department and education institutions based on the national regulations; setting of administrative department and education institutions exist in name only and fail to play substantial guiding and management function for setting of public art courses. Therefore, "although many HEIs have set up the public art education institutions, they fail to carry out corresponding system design for separation of duties, development orientation, relevant policies, and so on of public art education institutions. [1]"

\section{B. Single Course Content and Forms}

The number of limited optional art courses that the Ministry of Education stipulated in the Public Art Course Guidelines for the National Regular Higher Education Institutions is eight, namely, Music Appreciation, Introduction to Art, Art Appreciation, Movie and TV Appreciation, Dance Appreciation, Drama Appreciation, Traditional Opera Appreciation and Calligraphy Appreciation. Public art courses in most of the non-government HEIs are set up mainly in accordance with eight courses stipulated in the Public Art Course Guidelines for the National Regular Higher Education Institutions issued by the Ministry of Education, but a few HEIs do not completely set up the eight limited optional art courses stipulated by the Ministry of Education. The setting 
content of the public art courses is mainly developed around the public art appreciation courses and is less developed based on the content of the public art courses in their own schools. The teaching form of the public art education courses is mainly classroom teaching and teaching modes and methods are relatively single.

\section{Weak Links in the Introduction of High-level Teaching Staff}

The Public Art Course Guidelines for the National Regular Higher Education Institutions issued in 2006 points out that "according to fundamental task and development requirements of art education in higher education institutions, the number of teachers that teach the public art courses in higher education institutions should account for $0.15-0.2 \%$ of the total number of students at school and the number of full-time teachers should account for $50 \%$ of the total number of art teachers". As to non-government HEIs in Henan Province, the construction of high-level teaching staff that engage in the public art education is relatively weak, which mainly include the following situations: Relied on school of music, school of dance, school of art and other relevant secondary professional schools set up by themselves and based on teaching staff of relevant secondary professional schools, a part of HEICs further arrange teachers that teach music and art profession courses to concurrently engage in the teaching work of the public art education; a part of HEIs adopt full-time teaching staff, part-time teaching staff or the teaching staff with the combination of full-time and part-time teachers to make up the teaching staff of the public art education and weaken the requirements for number of full-time teachers that engage in the teaching of the public art education stipulated by the Ministry of Education; a part of HEIs do not attach importance to the introduction work of high-level public art education teachers and healthy teaching staff has not formed for a long time. Therefore, teacher staff that engage in public art education is relatively deficient.

\section{Insufficient Funds of Public Art Education Activities}

1) Insufficiency of fund investment in public art education activities universally exists in the non-government HEIs: When a few non-government HEIs continually improve the school conditions, they have less fund investment in the public art education and very few student average fund. Faced with the transformation development in the new era, the nongovernment HEIs can improve the training quality of applied talents through the action of the service of the public art education and further promote the ability of the nongovernment HEIs to serve the local economy and social development.

2) Fund of public art education activities invested by nongovernment HEIs has weak sustainability: When part of nongovernment HEIs carry on public art educational activities, they unilaterally lay emphasis on timeliness, neglect the sustainability of the educational characteristic of public art educational activities, increase investment to relevant public art activities with strong timeliness and obviously has less investment in capital construction fund required in the public art teaching and funds to develop high -grade and high-level public art educational activities.

\section{E. Less Achievements in Teaching and Scientific Research}

Teachers that engage in the public art education in nongovernment HEIs have less achievement in teaching and scientific research. From the level of achievements, they have much less provincial level and above high-level achievements in teaching and scientific research. From the participation degree of achievements, all kinds of teachings and scientific research projects hosted and participated by teachers that engage in the public art education accounts less proportion in the same level project research. Based on the investigation and research of the author in XX non-government HEIs in Henan Province, the number of the school-level teaching reform research projects and scientific research projects approved from 2014 to 2016 in the school is 169 in total and the number of research projects of the public art education is 3 , which accounts for $1.86 \%$ of the total number of projects.

\section{Concrete Measures to Advance the Public ART EDUCATION WORK}

\section{A. Establish Effective Management Institutions and Innovate Management Modes}

When the non-government HEIs set up the public art education committee and the public art education teaching center, they should clear and definite the division of labor of specific public art education work. The public art education committee should arrange and coordinate the teaching work, school and out-of-school art activities, campus culture and art environment construction and other work of public art courses of the whole school; the public art education teaching center should take full charge of the concrete implementation work of the public art teaching in the school and actively develop all teaching work of the public art education. The uniform organization structure can clear management permissions and management responbilities, lay a foundation for the development of the public art education work and really achieve the unified leadership and planning goal of the public art eucation work.

The public art education can cultivate the elegant esthetic sentiment and comprehensive humanistic quality of students and is also the primary way for implementation of aesthetic education in HEIs, In the practical work, the non-government HEIs should continually innovate management modes, improve the educating level, promote the integrated development of students and further highlight the connotative features of the school through the public art education. The "four-dimensional interactive educational management mode" in the Sias International University of Zhengzhou University, the unique Sino-Foreign cooperative education institution in Henan Province, ensures the implementation of international whole-person education and improvement of the teaching level of the public art education. The University builds the leadership system made up of the administrative department, the Party committee and the board of supervisors to implement all-round management to the daily works of the University, which safeguards the law-based management and the standard 
management of the University; the teaching guiding committee, the academic board and the teaching steering committee made up of experts and scholars and the expert participation school system made up of the personnel appraisal supervision team of professors play important roles in teaching management, academic management and personnel management of the University; through "the student assistant team of the dean", the personnel appraisal supervision team attended by students, the annual teacher-student dialogue meeting and other forms, students in the University achieve participation in management; through setting of the parent supervision committee, the annual parent meeting held on the "Day of Visiting the University" and so on, the parent supervision management puts into effect.

\section{B. Enrich Course Content and Forms and Arouse the Learning Interest of Students}

Owing to the development of the modern network, the requirements of students to the setting of selective public art courses continually improve with broadening of their visions. Therefore, only when the HEIs constantly increase the number of the selective public art courses and optimize the structure can they meet the development needs of students. As to the course system, the HEIs should newly increase several selective public art courses each year on the basis of setting of eight limited optional art courses stipulated by the Ministry of Education for learning of all students. Take some local comprehensive universities for examples, some local HEIs start to set up public art courses through the combination with local folk artists such as Folk Art Appreciation (including operas, paper-cut and so on). The participation of local craft artists not only highlights the local characteristics and increases the learning interest of students but also advances the spread and development of local excellent folk culture in HEIs[2]. Considering the central plain culture has long history and important status, non-government HEIs in Henan Province should set up art courses that can highlight the local culture characteristics, such as Central Plain Folk Custom, Central Plain Drama Appreciation, Henan in History, and other courses to broaden the horizon of students and enhance the sense of identity of students to the culture of Henan. In addition, they can fully utilize the resource platform of the education information construction such as high-quality network educational resources and national level excellent course resources, organize diversified public art courses, arouse the enthusiasm of students to participate in the public art education and attain the goal that all students can mutually share the public art education course resources.

\section{Strengthen the Teaching Staff Construction of the Public Art Education}

The non-government HEIs should further strengthen the introduction of high-level teaching staff of the public art education, adopt full-time teachers-oriented and part-time teachers-supplemented teaching staff measures and improve the talent training quality. They should introduce the high-level applied academic research plus practice teachers from music and art circles to make up the difficult introduction situation of teaching staff of the public art education and promote the level of the public art education of their schools; they should require the part-time professors to conduct 4 academic lectures at least for all students each year to strengthen the construction of teaching team and promote the artistic accomplishment of students; they should intensify public art education edification to all students from different majors, further strengthen the cultivation to the existing teaching staff and fully promote the teaching staff construction level of the public art education.

They should keep enhancing the introduction of highquality network courses, fully utilize the well-known teacher and school resources to promote the learning of students to the public art courses, and gradually allow teachers of public art education courses in non-government HEIs to remark on the courses as hosts of courses and guide students so as to gradually reform and weed out stereotyped and backward courses and achieve the combination among personnel aspect, school aspect and social aspect.

\section{Increase the Fund Investment in the Public Art Education}

Fund investment is an important safeguard for the construction and development of the public art education. Non-government HEIs have single school fund resources and uneven fund investment in the public art education. In order to highlight the educational function of the public art education in HEIs, the non-government HEIs must further increase the fund investment in the construction of the public art education, strive to improve the school conditions of the public art education, increase the investment in the teaching and scientific research funds of the public art education, actively promote the construction strength of excellent courses of the public art education, improve the education and teaching funds of the public art education year by year and fully intensify the role of the public art education in the improvement of the talent training quality.

In order to make all students mutually share the teaching achievements of the public art education and fully strengthen the construction investment strength of the excellent courses of the public art education, superior education institutions need to support the non-government HEIs and provide more policy support to the construction of public art courses in the nongovernment HEIs.

\section{E. Enhance the Cultivation Work of Achievements in Teaching and Scientific Research}

The public art courses in HEIs need further summary and exploration in teaching practice in selection of teaching content, application of teaching modes and methods and other aspects. The non-government HEIs should encourage teachers to develop the discussion activities related to the public art education teaching work, actively mobilize and organize all full-time and part-time teachers to develop the public art teaching and scientific research work, actively declare all provincial level scientific research projects, write scientific research papers, rapidly transform the scientific research achievements to the teaching promotion motive of public art courses and further increase the cultivation strength of achievements in teaching and scientific research. 


\section{F. Reinforce the Local and International Art and Culture Exchange and Corporation}

Reinforcement of the public art education is not only to publicize the achievements of concrete practical activities of the campus public art education but to actively create conditions and opportunities to implement the Go-Out Strategy. The non-government HEIs should strive for the bid of many art activities of provincial level units, musician association and other units through active communication and strive to make non-government HEIs become the important exchange base of the provincial level art education achievements so as to promote the influence and popularity of the non-government HEIs. Meanwhile, the public art education in non-government HEIs should insist on cooperative education, strive to develop friendly exchange and cooperation with HEIs in many countries and regions around the world and ensure that any performance activity of local and international performance teams at the school serves all students from different majors because this kind of open exchange performance can promote students to be deeply influenced by the Chinese and western art and culture, have wide coverage and be welcomed by students; the non-government HEIs should draw up the annual local and international performance and exchange plan of the public art education and invite well-known artists at home and aboard to carry on exchange and conduct lectures at their schools.

\section{CONCLUSION}

The public art education in HEIs is a systematic project. Therefore, when handling internal and external relationships faced by the public art education in HEIs, non-government HEIs in Henan Province should correctly grasp the nonprofit, appropriateness, artistry and educational characteristic of the public art ed. Non-government HEIs in Henan Province are deeply influenced by the central plain culture. Therefore, the unique public art education courses constructed on the basis of the development characteristics of the central plain culture are bound to provide powerful safeguard for the development of the public art education in non-government HEIs in Henan Province.

\section{REFERENCES}

[1] Pang Haishao. Difficulties and Solutions of the Public Art Education in Colleges and Universities [J]. China Higher Education Research, 2015(12):77.

[2] Shao Ping. Exploration on Development Strategies of the Public Art Education in the Contemporary Colleges and Universities [J].Heilongiiang Researches on Higher Education, 2015 (3):85. 